\title{
PEMETAAN DAERAH POTENSIAL PENANGKAPAN IKAN TONGKOL (Euthynnus sp) DI PERAIRAN SELAT MAKASSAR
}

\section{MAPPING POTENTIAL AREAS OF FISHING FOR MACKAREL TUNA (Euthynnus SP) IN THE MAKASSAR STRAIT WATERS}

\author{
Fadli Yunus ${ }^{1}$, Mukti Zainuddin ${ }^{1 *}$, St Aisjah Farhum ${ }^{1}$ \\ ${ }^{1)}$ Program Studi Pemanfaatan Sumberdaya Perikanan, Fakultas Ilmu Kelautan dan Perikanan, Universitas \\ Hasanuddin
}

Diterima: 27 Januari 2019; Disetujui: 23 Februari 2019

\begin{abstract}
ABSTRAK
Penelitian ini bertujuan untuk mengidentifikasi hubungan antara hasil tangkapan Ikan Tongkol (Euthynnus $s p$ ) dengan faktor oseanografi dan memetakan Zona Potensial Penangkapan Ikan Tongkol (Euthynnus sp) di Perairan Selat Makassar. Data yang digunakan pada penelitian ini adalah data lapangan dan parameter oseanografi dari Juli hingga Oktober 2018, kemudian diolah dan dianalisis di Laboratorium Sistem Informasi Perikanan dan Geospasial Kelautan, UNHAS. Metode yang digunakan adalah metode survei untuk memperoleh data primer. Sedangkan data sekunder berupa data citra suhu permukaan laut (SST), Klorofil - a dan Salinitas. Analisis data menggunakan fungsi GAM untuk mengetahui parameter yang paling berpengaruh. Pembuatan peta zona potensial penangkapan ikan tongkol menggunakan Softwere Arcgis. Hasil analisis menunjukkan bahwa parameter yang berpengaruh terhadap hasil tangkapan adalah klorofil - a $\left(0.21-0.24 \mathrm{mg} / \mathrm{m}^{3}\right)$, suhu permukaan laut $\left(28.5-29.5{ }^{\circ} \mathrm{C}\right)$ dan salinitas $(32.6-33.0 \mathrm{ppt})$. Zona potensial penangkapan ikan tongkol secara spasial umumnya berada pada titik koordinat antara $3^{\circ} 23^{\prime} 28.37^{\prime \prime}$ LS sampai $5^{\circ} 33^{\prime} 19.33^{\prime \prime}$ LS dan antara $117^{\circ} 0$ '43.21 " BT sampai $119^{\circ} 34^{\prime} 31.96$ " BT.
\end{abstract}

Kata kunci : Tongkol, zona potensial penangkapan, Klorofil-a, SPL, salinitas, GAM

\begin{abstract}
This study aims to identify the relationship between the catch of tuna mackarel (Euthynnus sp) and oceanographic factors and map the Potential Zones of tuna mackarel (Euthynnus sp) Fishing in the Makassar Strait Waters. The data used in this study are field data and oceanographic parameters from July to October 2018, then processed and analyzed at the Marine and Geospatial Information System Laboratory of Marine, UNHAS. The method used is the survey method to obtain primary data. While secondary data in the form of image data of sea surface temperature (SST), Chlorophyll - a and Salinity. Data analysis uses the GAM function to find out the most influential parameters. Making a map of potential tuna Mackarel fishing zones using Arcgis Softwere. The results of the analysis show that the parameters that affect the catch are chlorophyll-a (0.21 - $0.24 \mathrm{mg} / \mathrm{m3})$, sea surface temperature $(28.5-29.5 \mathrm{OC})$ and salinity (32.6 - $33.0 \mathrm{ppt})$. Spatial potential zones of tuna mackerel fishing are generally located at the coordinates between 3023 '28.37' LS to 5033 '19.33' LS and between 11700 '43 .21 'BT to 1190 34' 31.96 'BT.
\end{abstract}

Keywords: Tuna Mackarel, potential fishing zone, chlorophyll - a, SPL, salinity, GAM 
Contact person : Mukti Zainuddin

E-Mail :muktizunhas@gmail.com

\section{PENDAHULUAN}

Ikan tongkol (Euthynnus $s p$ ) merupakan salah satu komoditas utama ekspor di bidang perikanan Indonesia. Akan tetapi akibat pengelolaan yang kurang baik di beberapa perairan Indonesia, terutama disebabkan minimnya informasi waktu musim tangkap, daerah penangkapan ikan, disamping kendala teknologi tangkapnya itu sendiri, tingkat pemanfaatan sumberdaya ikan menjadi sangat rendah (Zulkhasni dan Andriyeni, 2014).

Wilayah Pengelolaan Perikanan Republik Indonesia 713 (WPP-RI 713) merupakan kawasan perairan meliputi Samudera Pasifik, Selat Makassar, Teluk Bone, dan Laut Flores dengan luas sekitar 605.300 $\mathrm{km}^{2}$, memilki potensi ikan pelagis sebanyak 193.600 ton per tahun (Dirjen Tangkap KKP, 2011).

Secara geografis Selat Makassar berbatasan dan berhubungan dengan Samudera Pasifik di bagian utara melalui Laut Sulawesi dan di bagian selatan dengan Laut Jawa dan Laut Flores, sedangkan bagian barat berbatasan dengan Pulau Kalimantan dan bagian timur dengan Pulau Sulawesi.
Dengan mengetahui parameter oseanografi terutama suhu dan klorofil - a optimum dari suatu spesies ikan pada suatu perairan, maka kita dapat menduga keberadaan kelompok ikan dan dapat digunakan untuk tujuan penangkapan (Tangke et al, 2015)

Data satelit sangat bermanfaat khususnya untuk mengkaji daerah potensial untuk penangkapan secara cepat, berulang dan sistematis dalam cakupan area yang luas. Dengan mengintegrasikan data oseanografi lapangan dengan data citra satelit serta data penangkapan ikan tongkol.

Berdasarkan informasi diatas., maka dianggap perlu melakukan penelitian tentang daerah potensial penangkapan ikan tongkol yang disajikan dalam bentuk pemetaan daerah penangkapan ikan. Diharapkan dari hasil penelitian ini menjawab permasalahan daerah penangkapan dalam hal produksi hasil tangkapan ikan tongkol di Perairan Selat Makassar.

\section{METODE PENELITIAN}

Waktu dan Tempat

Penelitian ini dilaksanakan pada Bulan Juli -

Oktober 2018 di Perairan Selat Makassar, Provinsi Sulawesi Selatan. 


\section{Metode Pengumpulan Data}

Metode pengambilan data yang di gunakan adalah metode survei dan pengumpulan dataset berupa data primer dan data sekunder. Data primer merupakan data yang diperoleh langsung di lapangan dengan cara mengikuti operasi penangkapan ikan menggunakan purse seine untuk mengumpulkan titik koordinat penangkapan dan hasil tangkapan di Selat Makassar, data sekunder berupa data citra satelit SPL, klorofil-a, dan salinitas yang di peroleh oleh dari Nasa Ocean Color. Untuk pengambilan data dilakukan beberapa tahap yaitu:

1. Persiapan diawali pencarian data sekunder tentang data yang ingin diambil, observasi lapangan, konsultasi dengan pihak terkait, serta menyiapkan alat dan bahan yang digunakan dalam pengambilan data.

2. Tahap pengambilan data yaitu Pengambilan data titik koordinat penangkapan yang meliputi lokasi penangkapan purse seine, data dikumpulkan berdasarkan titik hauling serta pengukuran beberapa parameter oseanografi yaitu suhu permukaan laut, kandungan klorofl-a, dan salinitas. Pengukuran suhu permukaan laut pada lokasi penangkapan menggunakan thermometer digital, pengukuran kandungan klorofil-a, dengan mengambil sampel air laut, pengukuran salinitas dengan menggunakan hendrefraktometer. Data lapangan selanjutnya dikorelasikan dengan data citra satelit. Hasil kolerasi menunjukkan bahwa terdapat hubungan antara data lapangan dengan data hasil citra satelit sehingga yang digunakan adalah data citra satelit untuk menjamin akurasi data secara global.

\section{Analisis Data}

Data primer yang diperoleh pada penelitian selanjutnya dianalisis dengan data sekunder. Untuk mencapai tujuan penelitian dengan analisis sebagai berikut

a. Data citra suhu permukaan laut yang digunakan adalah data bulanan. Data sebaran SPL secara horizontal dihitung meggunakan data citra SPL yang diperoleh dari NASA Oceancolor pada bulan Juli-Oktober 2018 untuk mengetahui suhu permukaan laut.

b. Data citra klorofil-a digunakan mengetahui kesuburan perairan Selat Makassar. Perhitungan kesuburan perairan didasarkan pada analisis kandungan klorofil-a yang diukur sensor MODIS.

C. Citra salinitas diperoleh dari Centre aval de Traitement des donnessSMOS 
(CATDS) dengan menganalisis salinitas perairan di lokasi penelitian.

d. Data hasil tangkapan antara bulan JuliOktober 2018 dianalisis dengan cara menghitung jumlah hasil tangkapan per hauling. Kemudian dilakukan analisis data hasil tangkapan dengan citar sebaran SPL, Klorofil-a, Salintas untuk menentukan daerah penangkapan ikan.

e. Genelized Additive Model (GAM)

Data bulanan konsentrasi SPL, klorofil $-a$, dan Salinitas di peroleh dari citra satelit dengan resolusi spasial $4 \mathrm{~km}$ yang kemudian di lakukan pengujian lanjutan dengan GAM. Model statistik yang digunakan adalah Generalized Additive Model (GAM) dengan $\mathrm{R}$ language program software (versi 3.3.2). GAM adalah model non-linear, biasanya di gunakan untuk memahami keterkaitan antara variable yang diamati melalui identifikasi kisaran nilai yang berpengaruh posistif. Variable respon $\mu$ i ( jumlah hasil tangkapan ikan tongkol dalam satuan ekor ) dan variable predictor (SPL, Klorofil-a, dan salinitas) yang dapat di formulasikan seperti persamaan berikut ini :

$g(\mu i)=\alpha^{\circ}+s_{1}(S P L)+s_{1}($ klorofil-a $)+s_{1}($ salinitas $)+\varepsilon$

$g$ = spline smooth function

$\mu \mathrm{i}=$ variable respon

$$
\begin{aligned}
\alpha^{\circ} & =\text { koefisien konstanta } \\
S_{n} & =\text { smoothing function dari variable } \\
& \text { predictor } \\
\varepsilon & =\text { standard eror }
\end{aligned}
$$

Sebelum dilakukan pemodelan GAM terlebih dahulu dilakukan ekslorasi dataset yang bertujuan untuk mengidentifikasi data pencilan kolinearitas antar setiap variable penjelas. Pemodelan GAM dilakukan dengan menggunakan mgcvpackage terdapat dalam $\mathrm{R}$ language. Pemodelan GAM dilakukan dengan menggunakan distribusi Guassin dan fungsi identitylink. Sebagai variabel respon adalah hasil tangkapan, sedangkan sebagai variabel penjelasnya adalah SPL, klorofil-a, dan Salinitas.

\section{HASIL DAN PEMBAHASAN}

\section{Aplikasi Sistem Informasi Geografis Parameter Oseanografi}

1. Suhu Permukaan Laut

Suhu Permukaan Laut (SPL) merupakan salah satu parameter yang menentukan kualitas perairan karena dapat mempengaruhi metabolism dan perkembangan organism laut (Emiyanti dkk, 2015).

Informasi sebaran suhu permukaan laut sangat penting untuk menentukan 
E-ISSN: 2614-5014

daerah potensial penangkapan ikan (Safruddin dan Zainuddin, 2007).

Sebaran suhu permukaan laut di peraran Selat Makassar pada bula Juli 2018 (Gambar 1) berkisar antara $28.00-31.84^{\circ} \mathrm{C}$. pada suhu $28.00-29.28^{\circ} \mathrm{C}$. tangkapan terbesar pada bulan Juli sebanyak 120 ekor pada suhu $28.77^{\circ} \mathrm{C}$ sedangkan terendah $28.68^{\circ} \mathrm{C}$. Sebaran titik penangkapan terdapat antara 117.7 - 118.4 BT dan 3.9 - 4.2 LS.

Distribusi penangkapan ikan pada bulan Juli

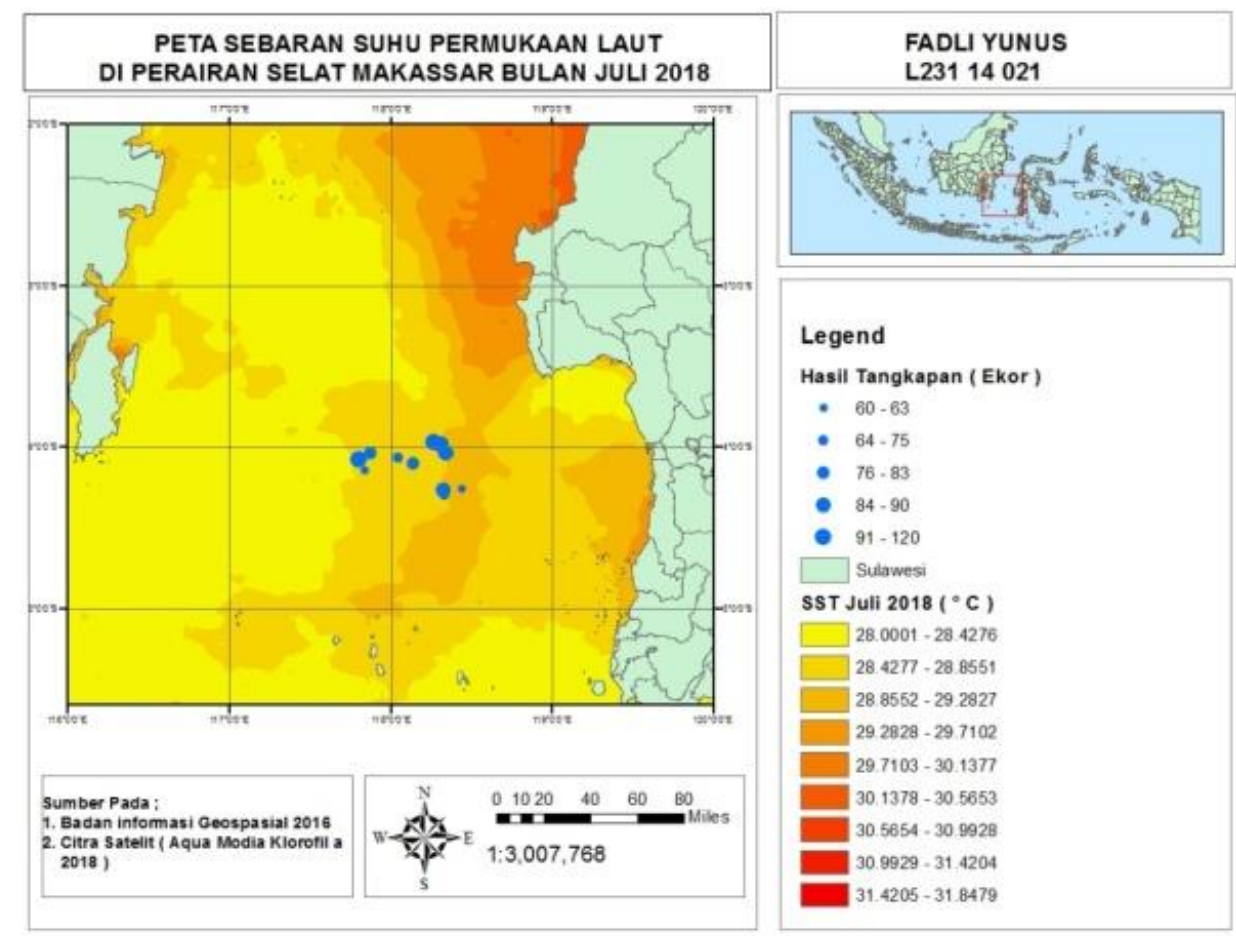

Gambar 1. Peta Sebaran SPL bulan Juli 2018

Sebaran suhu permukaan laut di perairan Selat Makassar pada bulan Agustus 2018 (Gambar 2) berkisar antara 28.00- 31.84 ${ }^{0} \mathrm{C}$. Distribusi penangkapan ikan paada bulan Agustus pada suhu $28.00-29.28{ }^{\circ} \mathrm{C}$. Tangkapan terbesar 62 ekor pada suhu 29.52
${ }^{0} \mathrm{C}$. Sedangkan tangkapan terendah sebanyak 37 ekor pada suhu $29.41{ }^{\circ} \mathrm{C}$. Sebaran titik penangkapan terdapat antara 119.3 - 119.4 BT dan $4.0-4.1$ LS. 


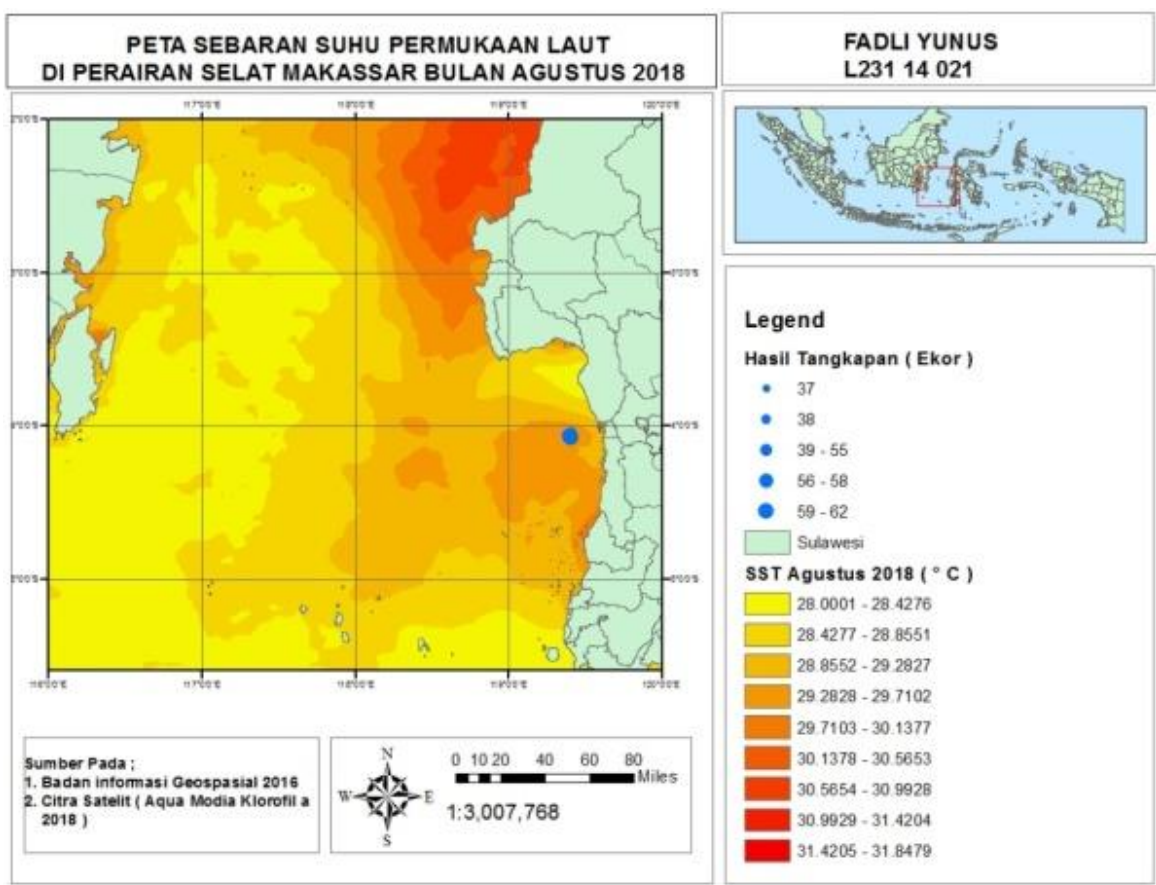

Gambar 1. Peta Sebaran SPL bulan Agustus 2018

Sebaran suhu permukaan laut di perairan Selat Makassar pada bulan September 2018 (Gambar 3) berkisar antara $28.00-31.84^{\circ} \mathrm{C}$. Distribusi penangkapan ikan pada bulan September pada suhu 28.00 $29.71{ }^{\circ} \mathrm{C}$. Tangkapan terbesar pada bulan
September sebanyak 230 ekor pada suhu $29.32{ }^{\circ} \mathrm{C}$. Sedangkan tangkapan terendah sebanyak 84 ekor pada suhu $29.01{ }^{0} \mathrm{C}$. Sedangkan titik penangkapan terdapat antara 117.6 - 118.4 BT dan 3.7 - 4.3 LS.

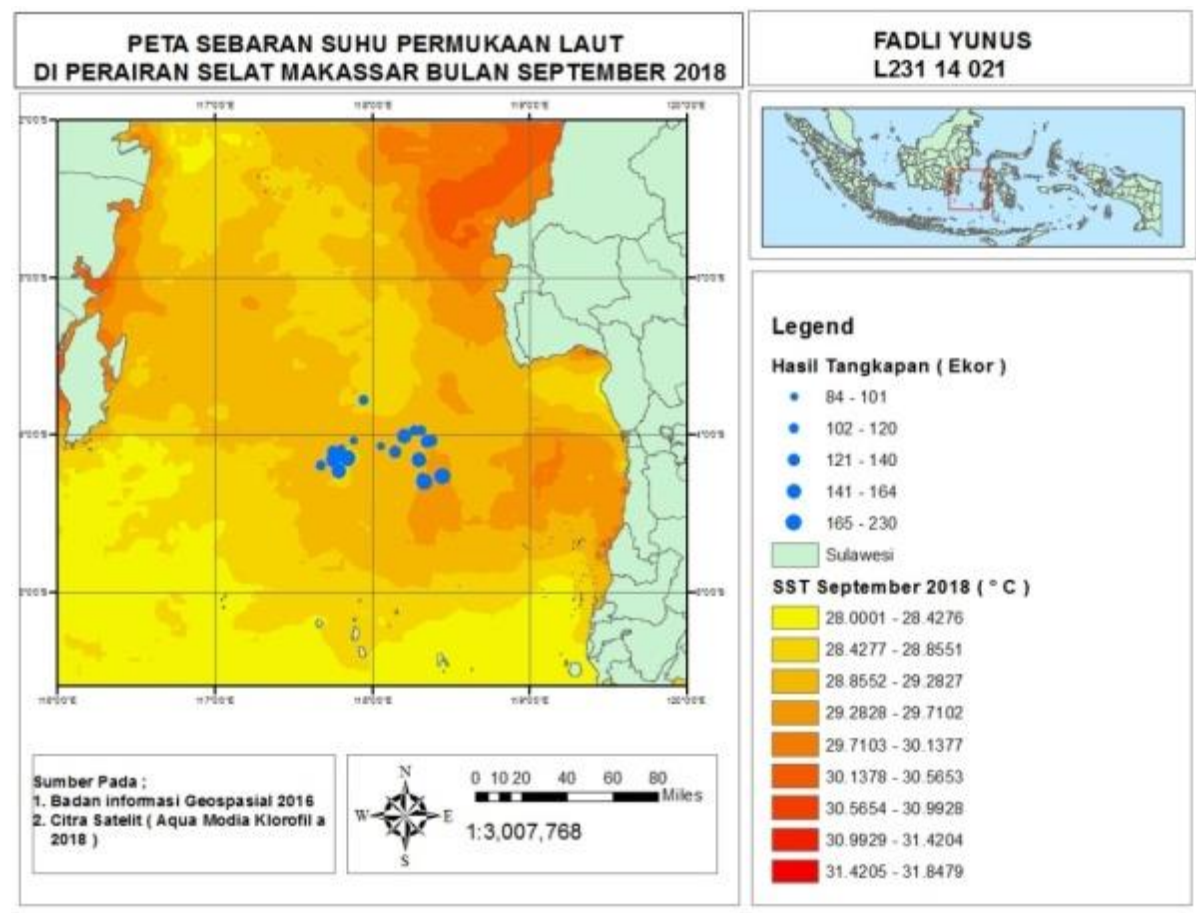

Gambar 3. Peta Sebaran SPL bulan Sepetember 2018 
Sebaran suhu permukaan laut di perairan Selat Makassar pada bulan Oktober 2018 (Gambar 4) berkisar antara 28.00- 31.84 ${ }^{0} \mathrm{C}$. Distribusi penangkapan ikan pada bulan Oktober pada suhu $28.00-30.99{ }^{\circ} \mathrm{C}$. Tangkapan terbesar pada bulan Oktober sebanyak 293 ekor pada suhu $30.63{ }^{\circ} \mathrm{C}$. Sedangkan tangkapan terendah sebanyak 125 ekor pada suhu $30.49{ }^{\circ} \mathrm{C}$. Sebaran titik penangkapan terdapat antara 117.5 - 119.3 BT dan $3.7-4.5$ LS.

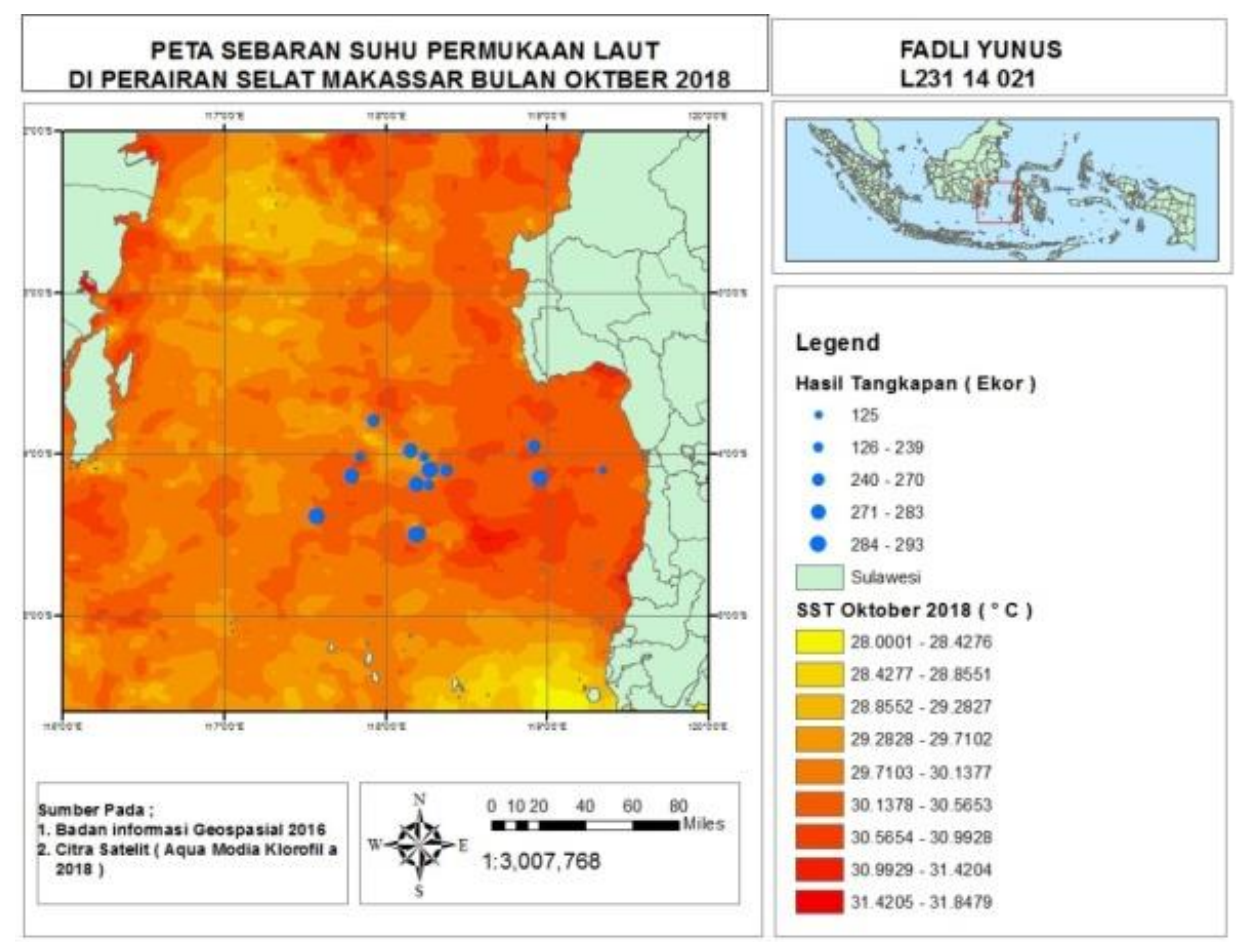

Gambar 4. Peta Sebaran SPL bulan Oktober 2018

2. Klorofil-a

Konsentrasi klorofil-a yang dikenal sebagai pigmen photosintetik dari phytoplankton. Pigmen ini dianggap sebagai indeks terhadap tingkat produktifitas biologia. Di perairan laut, indeks klorofil - a merupakan gambaran biomassa fitiplankton (Gomez et al., 2012). Ini dapat dihubungkan dengan produksi ikan atau lebih tepatnya dapat menggambarkan tingkat produktifitas daerah penangkapan ikan (Polovina et al., 2001). Distribusi ikan tongkol dipengaruhi kondisi oseanografi secara spasial dan temporat. Ketersediaan makanan baik dalam jumlah dan kualitas mempengaruhi tingkat predasi dan merupakan variable penting bagi populasi tongkol. Ketersediaan makanan berhubung dengan rantai makanan (food chains). Plankton timbuhan (phytoplankton) melalui proses fotosintesis dapat memproduksi bahan organic (produsen primer) (Jufri dkk, 2014).

Sebaran klorofil-a di perairan Selat Makassar pada bulan Juli 2018 (Gambar 5) 
berkisar antara $0.09-1.49 \mathrm{mg} / \mathrm{m}^{3}$. Distribusi penangkapan ikan pada bulan Juli pada kandungan korofil-a $0.09-0.40 \mathrm{mg} / \mathrm{m}^{3}$. Tangkapan terbesar pada bulan Juli sebanyak 120 ekor pada kandungan klorofil-a 0.27 $\mathrm{mg} / \mathrm{m}^{3}$. Sedangka tangkapan terendah

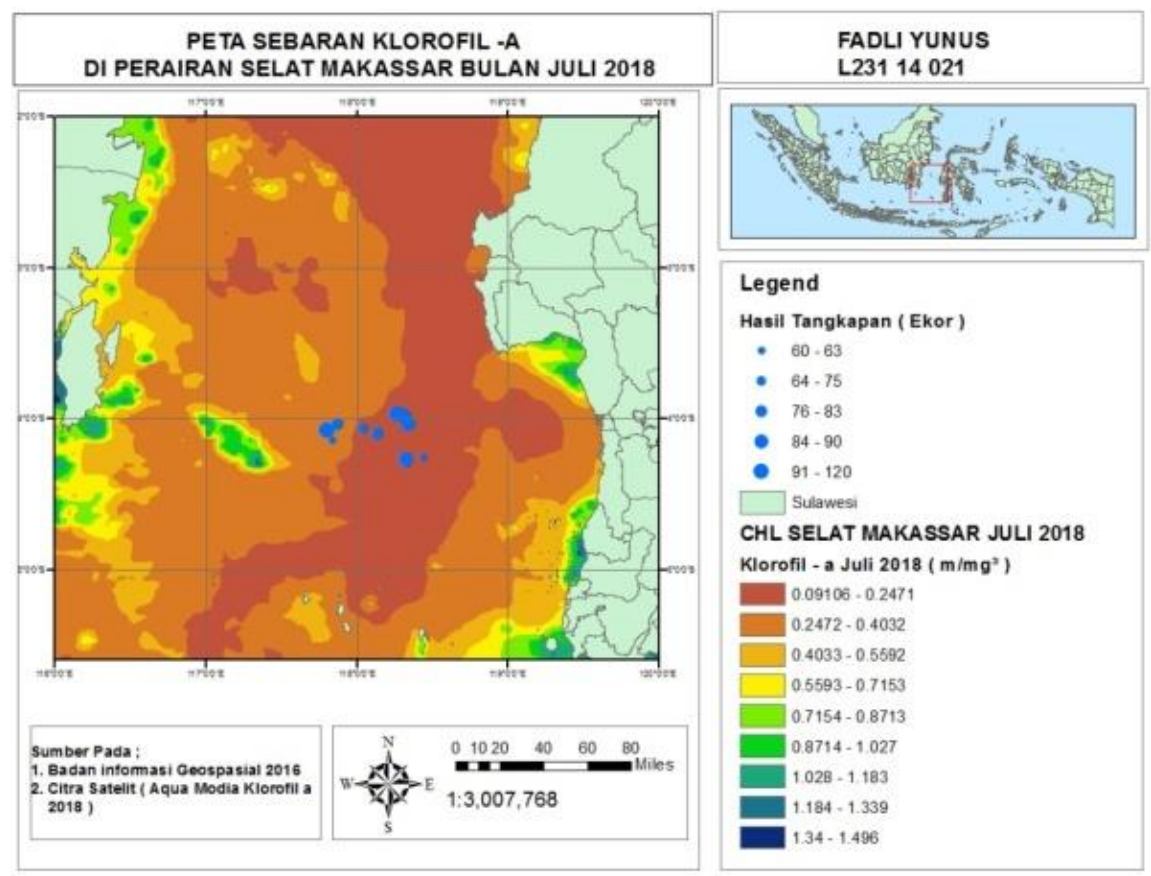

Gambar 5. Peta Sebaran Klorofil - a bulan Juli 2018

Sebaran klorofil-a di perairan Selat Makassar pada bulan Agustus 2018 (Gambar 6) berkisar antara $0.09-1.49 \mathrm{mg} / \mathrm{m}^{3}$. Distribusi penangkapn ikan pada bulan Agustus pada kandungan klorofil-a 0.09 $0.24 \mathrm{mg} / \mathrm{m}^{3}$. Tangkapan terbesar pada bulan Agustus sebanyak 62 ekor pada kandungan sebanyak 60 ekor pada kandungan klorofil - a $0.18 \mathrm{mg} / \mathrm{m}^{3}$. Sebaran titik penangkapan terdapat antara 117.7 - 118.4 BT dan $3.9-4.2$ LS. 


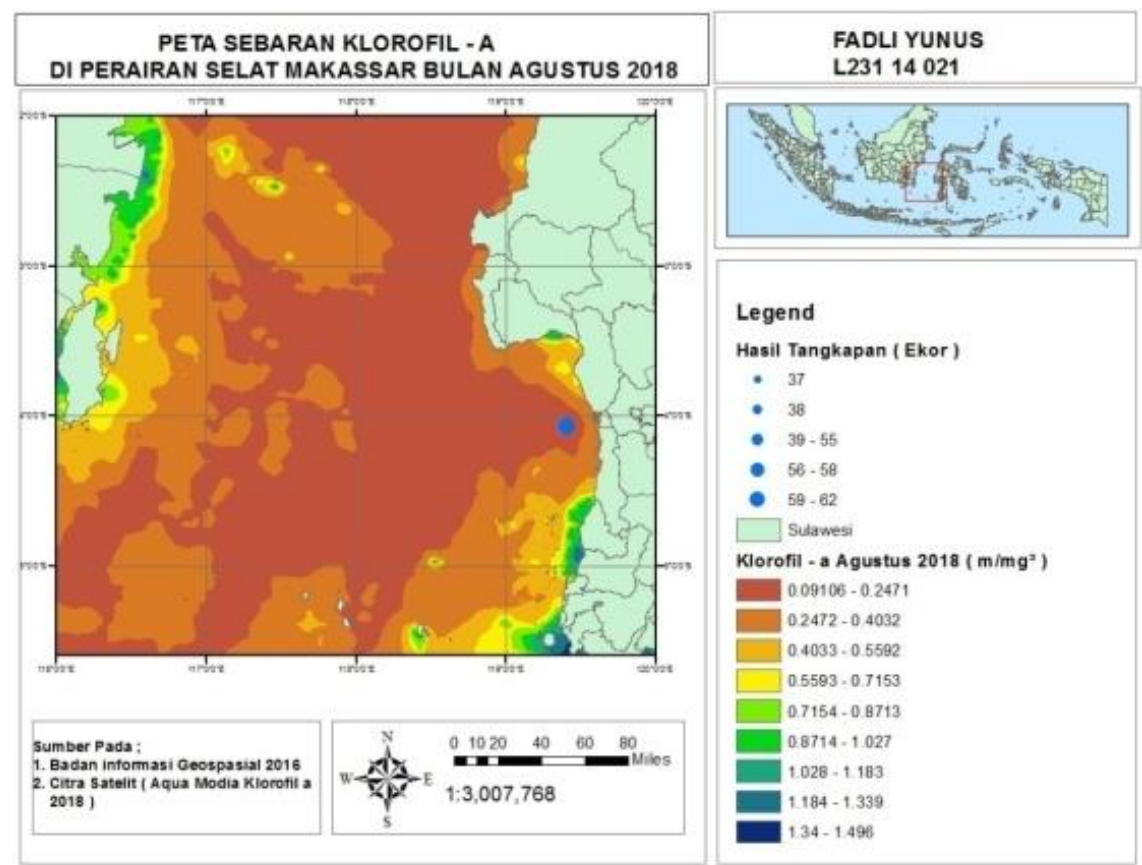

Gambar 6. Peta Sebaran Klorofil - a bulan Agustus 2018

Sebaran klorofil - a di perairan Selat Makassar pada bulan September 2018 (Gambar 7) berkisar antara $0.09-1.49$ $\mathrm{mg} / \mathrm{m}^{3}$. Distribusi penangkapn ikan pada bulan September pada kandungan klorofil - a $0.09-0,40 \mathrm{mg} / \mathrm{m}^{3}$. Tangkapan terbesar pada bulan September sebanyak 230 ekor pada kandungan klorofil - a $0.26 \mathrm{mg} / \mathrm{m}^{3}$ sedangkan tangkapan terendah sebanyak 84 ekor pada kandungan klorofil - a $0.23 \mathrm{mg} / \mathrm{m}^{3}$. Sebaran titik penangkapan terdapat antara 117.6 - 118.4 BT dan 3.7 - 4.3 LS.

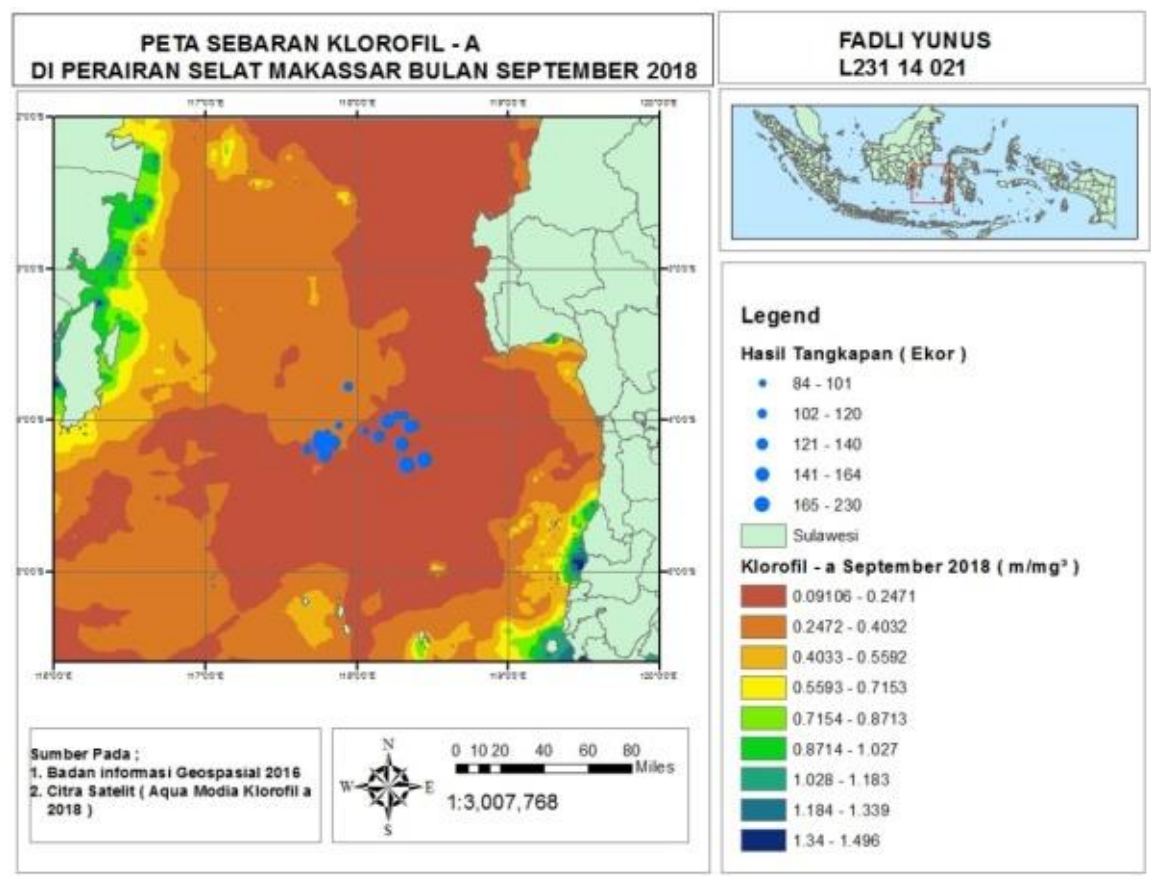

Gambar 7. Peta Sebaran Klorofil - a bulan September 2018 
Sebaran klorofi-a di perairan Selat Makassar pada bulan Oktober 2018 (Gambar 8) berkisar antara $0.09-1.49$ $\mathrm{mg} / \mathrm{m}^{3}$. Distribusi penangkapn ikan pada bulan Oktober pada kandungan klorofil-a $0.09-0.40 \mathrm{mg} / \mathrm{m}^{3}$. Tangkapan terbesar pada bulan Oktober sebanyak 298 ekor pada kandungan klorofil-a $0.24 \mathrm{mg} / \mathrm{m}^{3}$ sedangkan tangkapan terendah sebanyak 84 ekor pada kandungan klorofil-a $019 \mathrm{mg} / \mathrm{m}^{3}$. Sebaran titik penangkapan terdapat antara 117.5 119.3 BT dan $3.7-4.5$ LS.

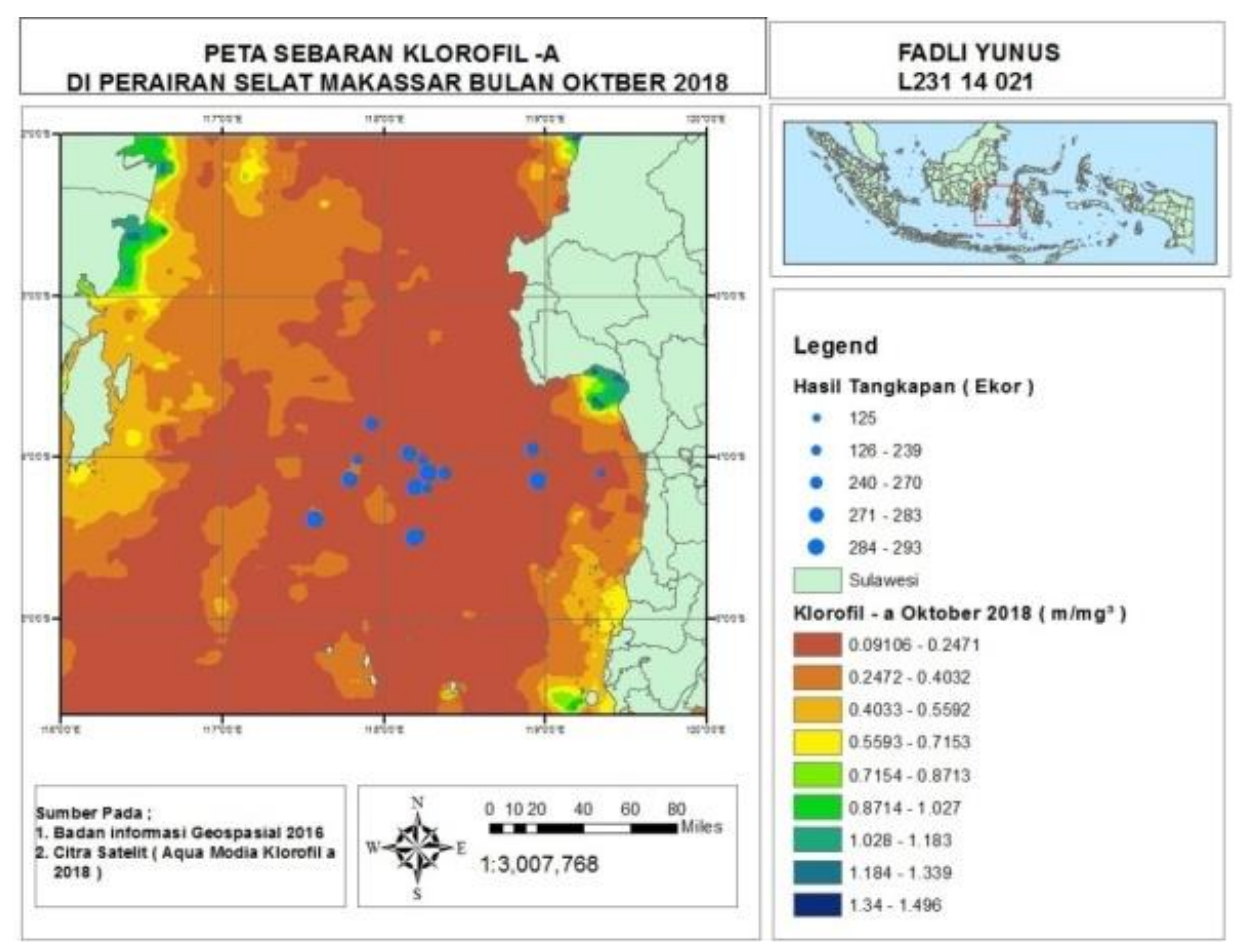

Gambar 8. Peta Sebaran Klorofil - a bulan Oktober 2018

\section{Salinitas}

Salintas sangat berpengaruh terhadap proses osmoregulasi biota laut terutama ikan. Ikan cenderung memilih medium dengan salinitas yang lebih sesuai dengan tekanan osmotic tubuh mereka masing - masing. Perubahan salinitas akan merangsang ikan untuk melakukan migrasi ketempat yang memilki salinitas yang sesuai dengan tekanan osmotic tubuhnya. Contoh: Seriola qiuqueradiata menyukai medium dengan salinitas 19 ppt, sedangkan ikan tongkol menyukai wilayah dengan kadar salinitas 32 35 ppt (Sandi, 2014).

Sebaran salinitas di perairan Selat Makassar pada bulan Juli 2018 (Gambar 9) berkisar antara 32.05 - 35.65 ppt. Distribusi penangkapn ikan pada bulan Juli pada salinitas 32.05 - 32.85 ppt. Tangkapan terbesar pada bulan Juli sebanyak 120 ekor pada salinitas 32.05 ppt sedangkan tangkapan terendah sebanyak 60 ekor pada salinitas 32.45 ppt. Sebaran titik penangkapan 
terdapat antara 117.7 - 118.4 BT dan $3.9-4.2$

LS.
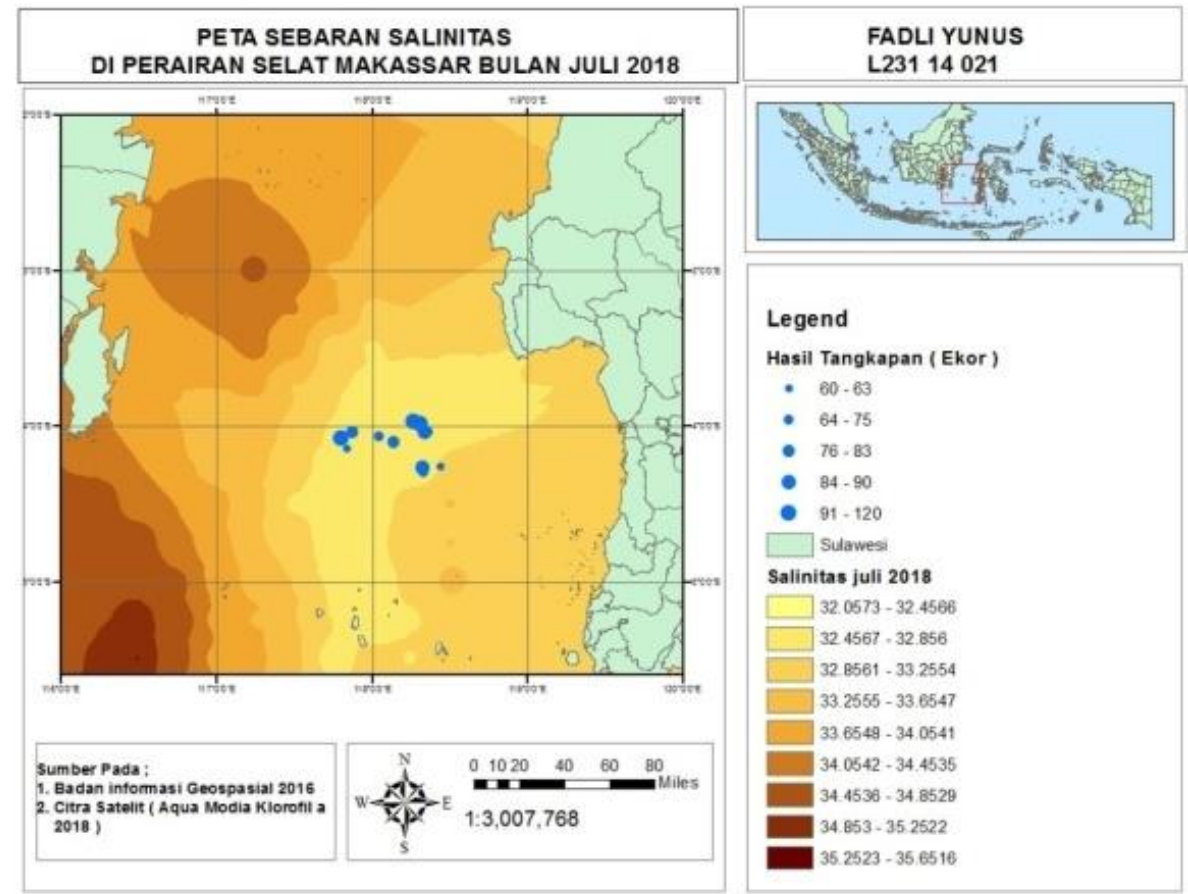

Gambar 9. Peta Sebaran Salinitas bulan Juli 2018

Sebaran salinitas di perairan Selat Makassar pada bulan Agustus 2018

(Gambar 10) berkisar antara 32.05 - 35.65 ppt. Distribusi penangkapn ikan pada bulan Agustus pada salinitas 32.85 - 33.65 ppt.
Tangkapan terbesar pada bulan Agustus sebanyak 62 ekor pada salinitas 32,50 ppt sedangkan tangkapan terendah sebanyak 37 ekor pada salinitas 32.75 ppt. Sebaran titik penangkapan terdapat antara 119.3 - 119.4 BT dan $4.0-4.1$ LS.

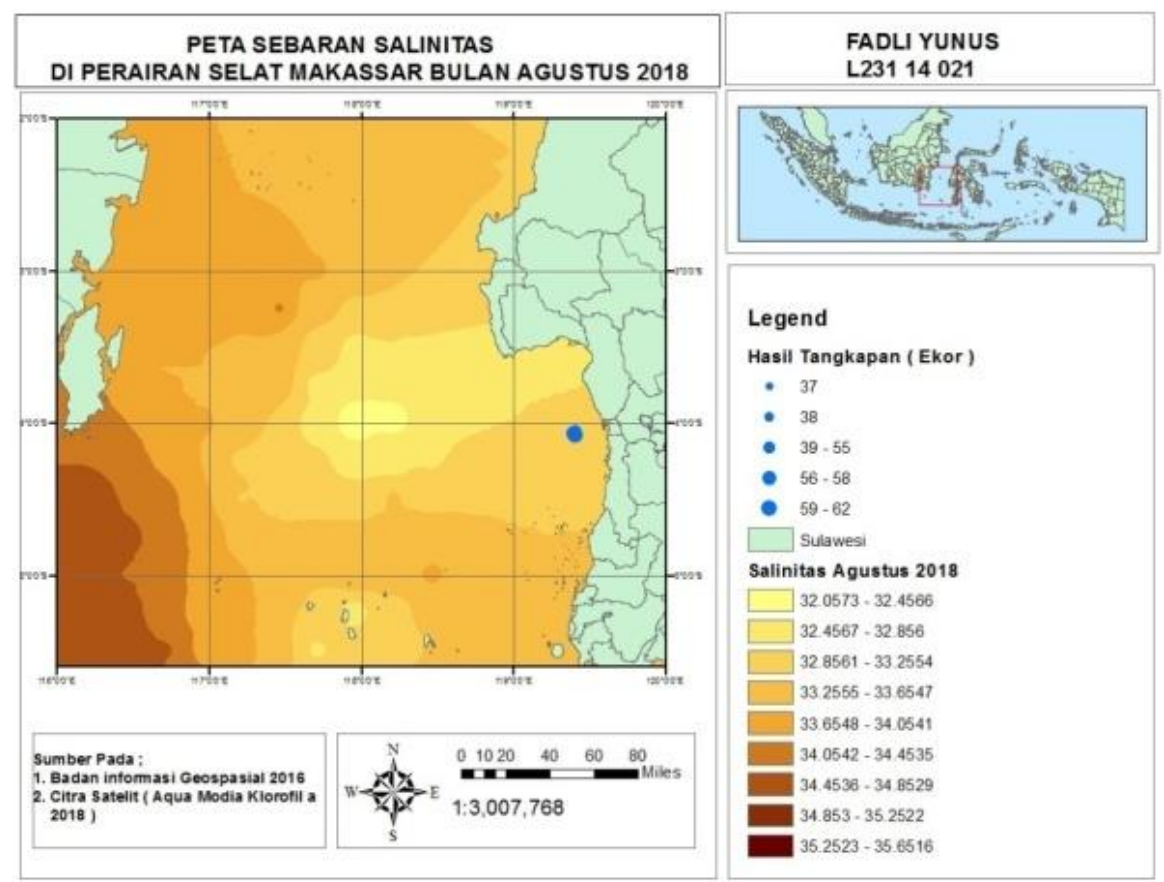

Gambar 10. Peta Sebaran Salinitas bulan Agustus 2018 
Sebaran salinitas di perairan Selat Makassar pada bulan September 2018 (Gambar 11) berkisar antara 32.05 35.65 ppt. Distribusi penangkapn ikan pada bulan September pada salinitas $32.05-32.85$ ppt. Tangkapan terbesar pada bulan
September sebanyak 230 ekor pada salinitas 32.81 ppt sedangkan tangkapan terendah sebanyak 84 ekor pada salinitas 32.46 ppt. Sebaran titik penangkapan terdapat antara 117.6 - 118.4 BT dan 3.7 - 4.3 LS.

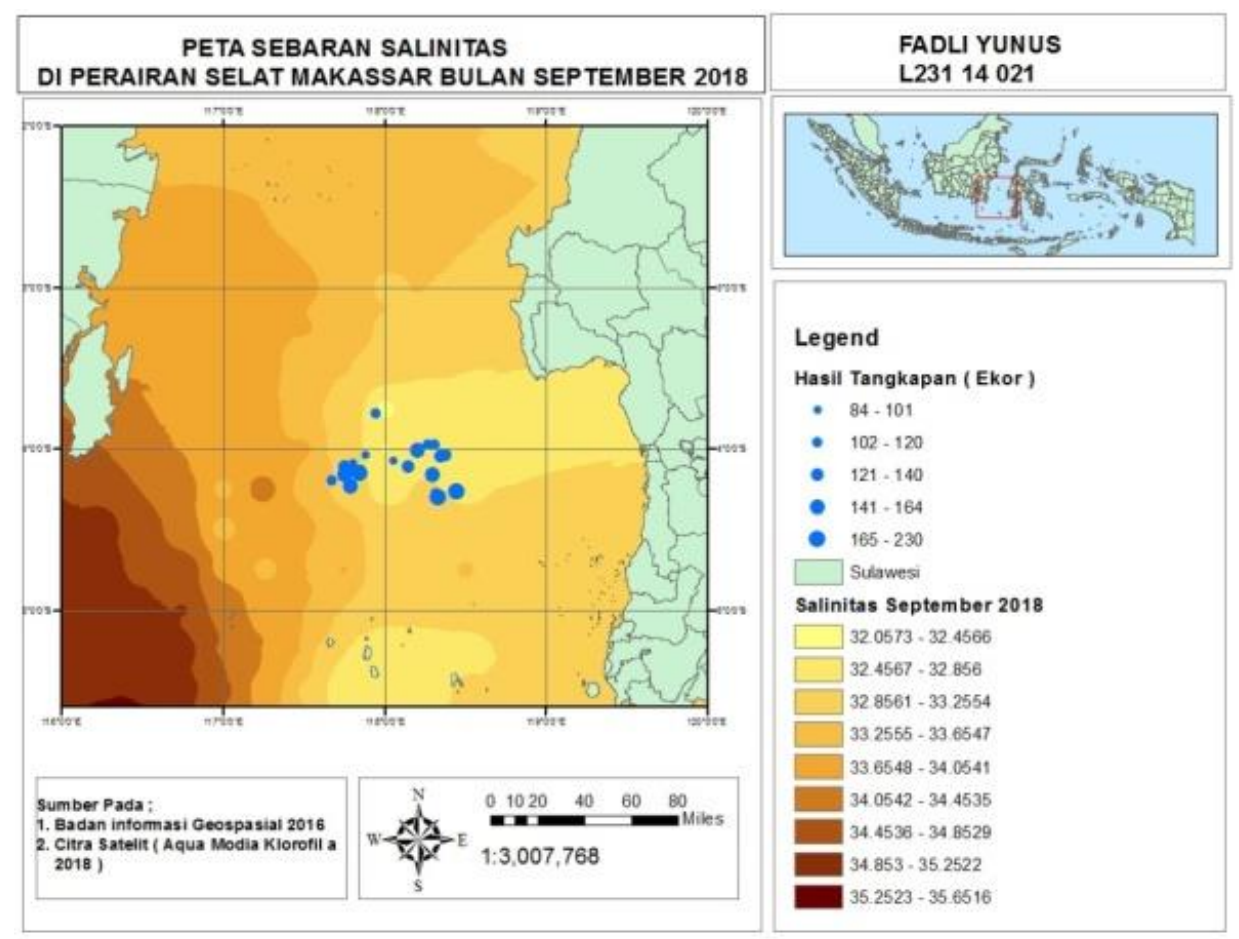

Gambar 11. Peta Sebaran Salinitas bulan September 2018

Sebaran salinitas di perairan Selat Makassar pada bulan Oktober 2018 (Gambar 12) berkisar antara $32.05-35.65$ ppt. Distribusi penangkapn ikan pada bulan Oktober pada salinitas 32.05 - 33.25 ppt. Tangkapan terbesar pada bulan September sebanyak 293 ekor pada salinitas 33.01 ppt sedangkan tangkapan terendah sebanyak 125 ekor pada salinitas 32.89 ppt. Sebaran titik penangkapan terdapat antara 117.5 - 119.3 BT dan $3.7-4.5$ LS. 


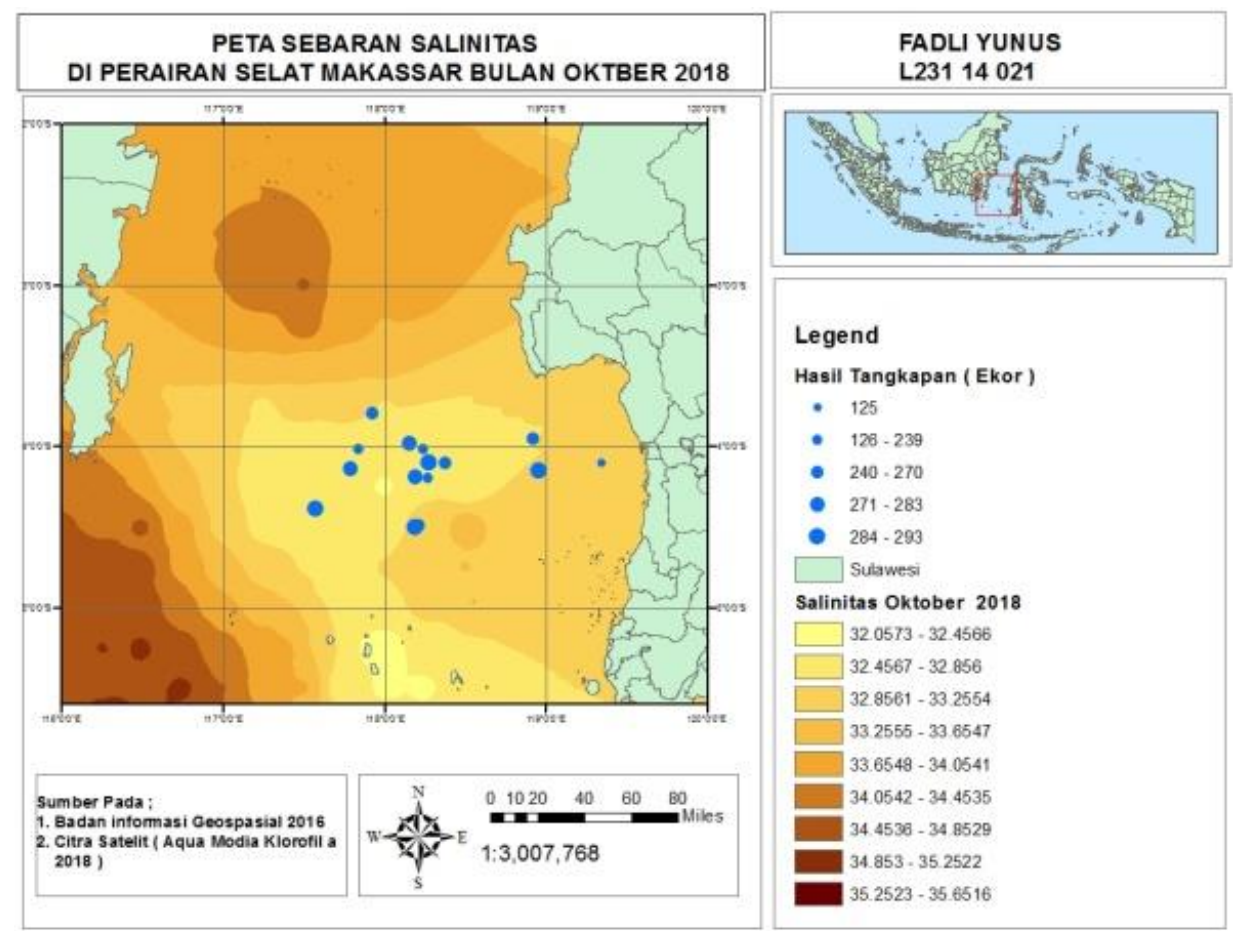

Gambar 12. Peta Sebaran Salinitas bulan Oktober 2018

Analisis Hubungan Hasil Tangkapan Ikan Tongkol (Euthynnus sp) Terhadap Faktor Oseanografi

Pada penelitian ini, analisis menggunakan metode GAM dari softwere $R$ (versi 3.4.2) dengan menggunakan salah satu fungsi GAM yaitu mgcv package untuk mengetahui hubungan antara hasil tangkapan sebagai variabel respons dengan beberapa variabel prediktor seperti suhu permukaan laut, klorofil - a, dan salinitas.

Tabel 1. Hasil analisis menggunakan metode GAM terhadap data hasil tangkapan dan faktor oseanografi

\begin{tabular}{|c|c|c|c|c|}
\hline & Df & $\mathbf{F}$ & & $p$-value \\
\hline s (Chl) & 3 & 3.2745 & & 0.03106 * \\
\hline s (Sst) & 3 & 2.4421 & & $0.07863^{\prime}$ \\
\hline \multirow[t]{2}{*}{ s (Salinitas) } & 3 & 2.5985 & & $0.06592^{\prime}$ \\
\hline & Signif.codes: 0 ** 0.001 & $‘ * *^{\prime} \quad 0.01$ ‘*’ & $0.05 \quad \because \quad 0.1$ & “ 1 \\
\hline
\end{tabular}

Berdasarkan analisis nilai signifikan klorofil - a, suhu permukaan laut dan salinitas menggunakan model GAM diperoleh nilai signifikan terhadap hasil tangkapan klorofil a dimana nilai dengan significansi $0.03106<$ 0.05 , sementara untuk suhu permukaan laut dan salinitas memiliki tingkat signifikan lebh rendah dari klorofil - a.

Berdasarkan dari nilai tiga parameter oseanografi dapat dikatakan bahwa klorofil a paling berpengaruh nyata terhadap hasil tangkapan ikan tongkol di Selat Makassar.

Terdapat hubungan yang nyata antara klorofil - a dengan hasil tangkapan diduga 
karena distribusi hasil tangkapan lebih mendekati area dengan produktivitas yang tinggi dan atau front antara massa air yang diketahui sebagai agregat konsentrasi makanan (Yamamoto dan Nizhizawa, 1986 dalam Waas, 2004).

Klorofil - a adalah salah satu tipe kloroffil yang paling umum yang terdapat pada tumbuhan. Klorofil - a di gunakan untuk mengetahui keberadaan fitiplakton dalam air. Fitoplankton adalah tumbuhan berukuran sangat kecil dan hidupnya terapung atau melayang - layang dalam kolom perairan, sehingga pergerakannya di pengaruhi oleh pergerakan air laut (Odum, 1971). Fitoplankton yang berada pada lapisan cahaya (fotik) mengandung klorofil - a yang
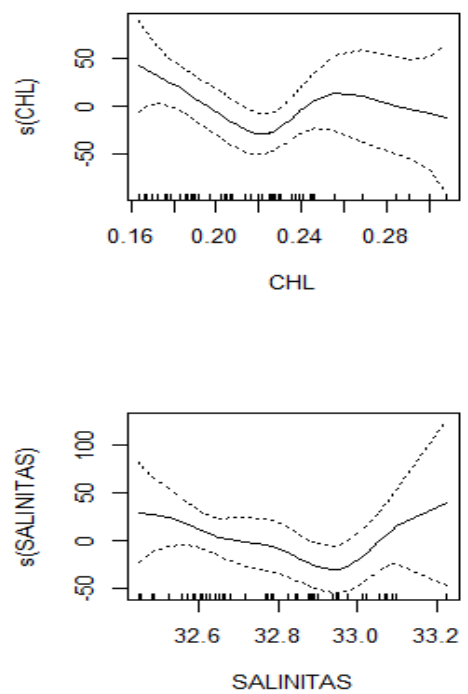

Gambar 13. Hubungan parameter oseonografi dengan hasil tangkapan ikan tongkol (Euthynnus sp)

berguna untuk fotosintesis. Klorofil - a mampu menyerap cahaya biru dan hijau, sehingga keberadaan fitiplankton dapat dideteksi berdasarkan kemampuan klorofil - a tersebut (Adnan, 2010).

Ikan tongkol (Euthynnus $s p$ ) di Perairan Kalimanan Timur, juga memiliki korelasic yang lebih tinggi kaitannya dengan parameter klorofil - a (adanya produktifitas primer) dari pada pesebaran SPL (Suhu Permukaan Laut).

Distribusi data selama peride penelitian untuk tiap parameter oseanografi dapat dilihat dengan melakukan uji GAM dari softwere $R$ dan selain itu juga untuk mengetahui klorofil - a lebih berpengaruh.

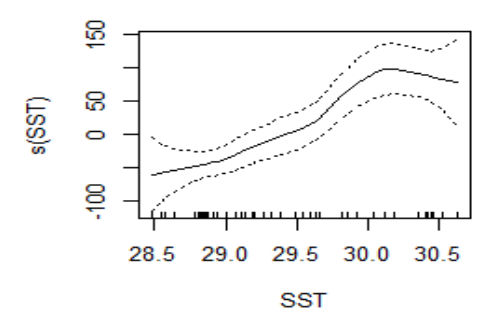

Hasil uji menujukkan pengaruh dari tiap parameter oseanografi klorofil-a, suhu permukaan laut, dan salinitas perairan perairan terhadap hasil tangkapan ikan tongkol selama periode penelitian, hasil dari analisis GAM selama bulan Juli - Oktober 2018. Sumbu $X$ menunjukkan nilai dari tiap variable yang di jelaskan dan sumbu $Y$ 
menunjukkan konstribusi smoother terhadap nilai yang di uji. Garis - garis kutip atau trick marks ("II $\left.{ }^{\prime \prime}\right)$ pada sumbu horizontal menggambarkan nilai tiap parameter pada titik penangkapan.

Hasil uji menunjukkan parameter oseanografi yang baik atau cenderung disukai dan melimpah untuk ikan tongkol pada saat penelitian untuk Klorofi-a berkisar antara 0.21 - $0.24 \mathrm{mg} / \mathrm{m}^{3}$, untuk SPL berkisar antara 28.5 - $29.5^{\circ}$ C, dan Salinitas berkisar antara 32.6 33.0 ppt.

Dari hasil ini telah diketahui mengapa Klorofil-a paling berpengaruh, sebab distribusi ikan tongkol lebih besar pada sebaran kolrofil-a $0.21-0.24 \mathrm{mg} / \mathrm{m}^{3}$.Menurut Adnan (2010) hubungan konsentasi klorofil-a dengan hasil tangkapan ikan tongkol terlihat dengan meningkatnya konsentasi klorofil-a menyebabkan hasil tangkapan yang meningkat, begitu pula juga sebaliknya penurunan konsentasi klorofi-a mengakibatkan hasil tangkapan yang menurun.

Berdasarkan penelitian sebelumnya (Mallawa et. al, 2016) dikatakan bahwa jumlah tangkapan nelayan purse seine di Selat Makassar tertinggi pada musim peralihan Barat ke Timur (April-Juni) dan pada saat musim Timur (Juli-Agustus). Sementara musim puncak berlangsung pada bulan Juli sampai Oktober. Serta menurut Zainuddin et. al. (2008) yang menyatakan konsentasi klorofil merupakan indikator yang baik pada habitat tuna albacora.

Penelitian lainnya tentang Zona Potensial Penangkapan Ikan (ZPPI) di Teluk Bone selama periode penelitian April-Juli di Teluk Bone memiliki karakteristik dengan SPL 29.5-31.5 ${ }^{\circ} \mathrm{C}$ daan desitas klorofil-a 0.15-0.35 $\mathrm{mg} \mathrm{m}^{3}$ (Zainuddin dkk, 2013).

Berdasarkan histogram (Gambar 14) menunjukkan bahwa kisaran SPL 28.5 - 29.0 ${ }^{0} \mathrm{C}$ untuk titik upaya penangkapan terbanyak selama bulan Juli - Oktober 2018. Sedangkan untuk upaya penangkapan sedikit pada SPL $28.0-28.5{ }^{\circ} \mathrm{C}$. Hal ini menunjukkan bahwa berdasarkan gambar histogram diatas ikan tongkol dominan tertangkap pada suhu yang relative hangat.

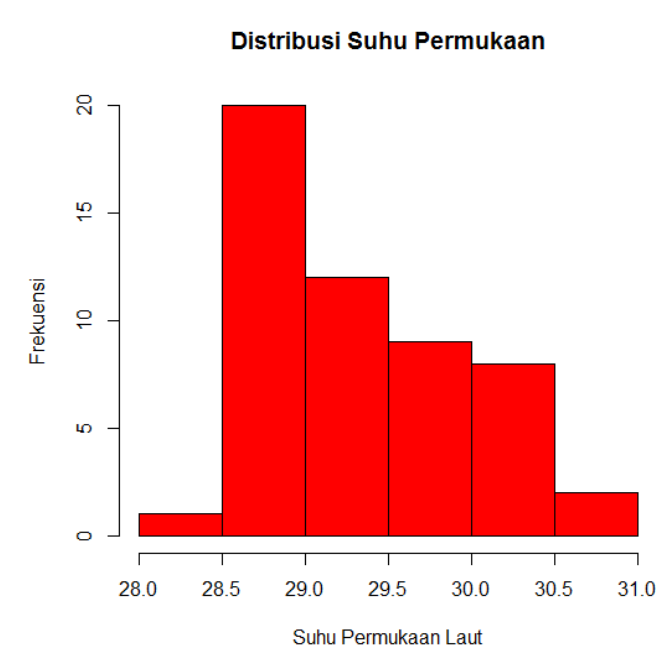

Gambar 14. Histogram Suhu Permukaan Laut pada bulan Juli - Oktober 2018

Berdasarkan histogram (Gambar 15) menunjukkan bahwa untuk frekuensi titik 
upaya penangkapan paling banyak pada kisaran perairan yang mengandung klorofil a antara $0.20-0.25 \mathrm{mg} / \mathrm{m}^{3}$. Jika dikaitkan dengan rantai makanan maka ikan banyak tertangkap pada perairan yang mengandung klorofil -a yang tinggi, namun hal ini disebabkan dengan posisi upaya penangkapan yang kebanyakan beroperasi pada area rumpon dan jauh dari garis pantai, sedangkan perairan yang mengandung klorofil-a tinggi berada pada area dekat garis pantai. Di laut, sebaran klorofil-a lebih tinggi konsentasinya pada perairan pantai dan pesisir, serta rendah di perairan lepas pantai. Tingginya sebaran konsentrasi klorofil-a di perairan pantai dan pesisir di sebabkan adanya suplay nutrien dalam jumlah besar melalui run-off dari daratan, sedangkan rendahnya konsentrasi klorofil-a di perairan lepas pantaai karena tidak adanya suplay nutrien dari daratan secara langsung (Prestiahadi,1994 dalam Hildayani, 2009).

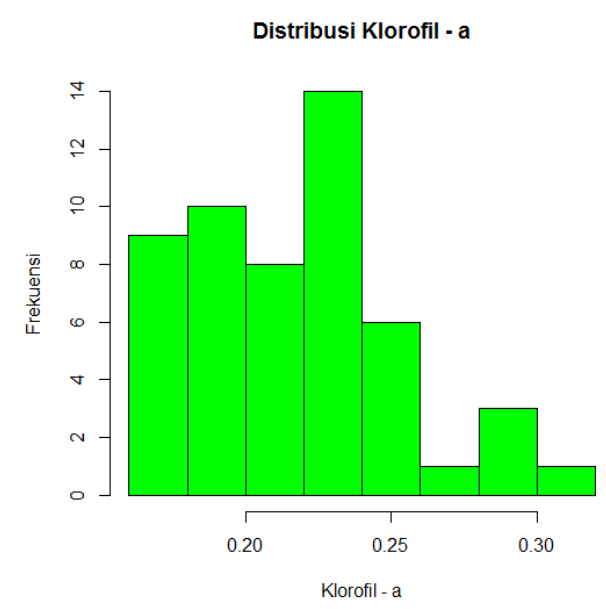

Gambar 15. Histogram Klorofil - a pada bulan Juli Oktober 2018
Berdasarkan histogram (Gambar 16) menunjukkan bahwa frekuensi titik upaya penangkapan paling banyak pada kisaran Salinitas perairan 32.6 - 32.7 ppt. Umumnya ikan tongkol (Euthynnus sp) tertangkap pada kedalaman 0-400 meter, salinitas perairan yang disukainnya berkisar 32-35 ppt (Nontji,1987). Pada histogram di atas menujukkan upaya penangkapan berada pada kisaran Salinitas 32.4 - 33.2 ppt.

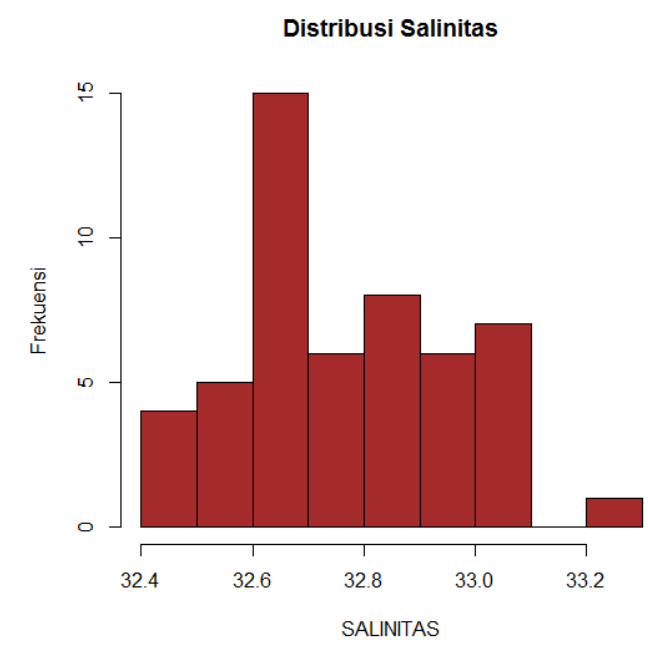

Gambar 16. Histogram salinitas pada bulan Juli Oktober 2018

\section{Pemetaan Zona Potensial Penangkapan Ikan Tongkol (Euthynnus sp)}

Berdasarkan nilai-nilai dari hasil analisis maka selanjutnya dilakukan overlay penggabungan parameter oseanografi yang telah diteliti untuk mendapatkan zona potensial atau luasan area yang menjadi zona potensial penangkapan ikan tongkol (Euthynnus sp) di Perairan Selat Makassar. Pemetaan zona potensial penangkapan ikan 
Jurnal IPTEKS PSP. Vol. 6 (11) April 2019: 1-20

tongkol (Euthynnus sp) menggunakan parameter oseanografi optimum (suhu permukaan laut, klorofil-a dan salinitas ).

Gambar 39 menunjukkan zona potensial penangkapan ikan tongkol (Euthynnus sp) pada bulan Juli di Selat Makassar. ZPPI ini terbentuk dari hasil overlay pertemuan antara parameter oseanografi yang optimum membentuk luasan area di perairan yang diduga sebagai ZPPI ikan tongkol. Total luas ZPPI tersebut $16.537,462$ $\mathrm{Km}^{2}$.

Zona potensial penangkapan ikan pada bulan Juli berada pada titik koordinat $\operatorname{antara} 3^{0} 23^{\prime} 28.37^{\prime \prime}$ LS sampai $5^{0} 27^{\prime} 12.14$ " LS dan antara117 033 ' 50.59 " BT sampai 119 '33 ' 46.27 " BT atau berada pada sebelah barat Kabupaten Majene sampai Kabupaten Takalar.

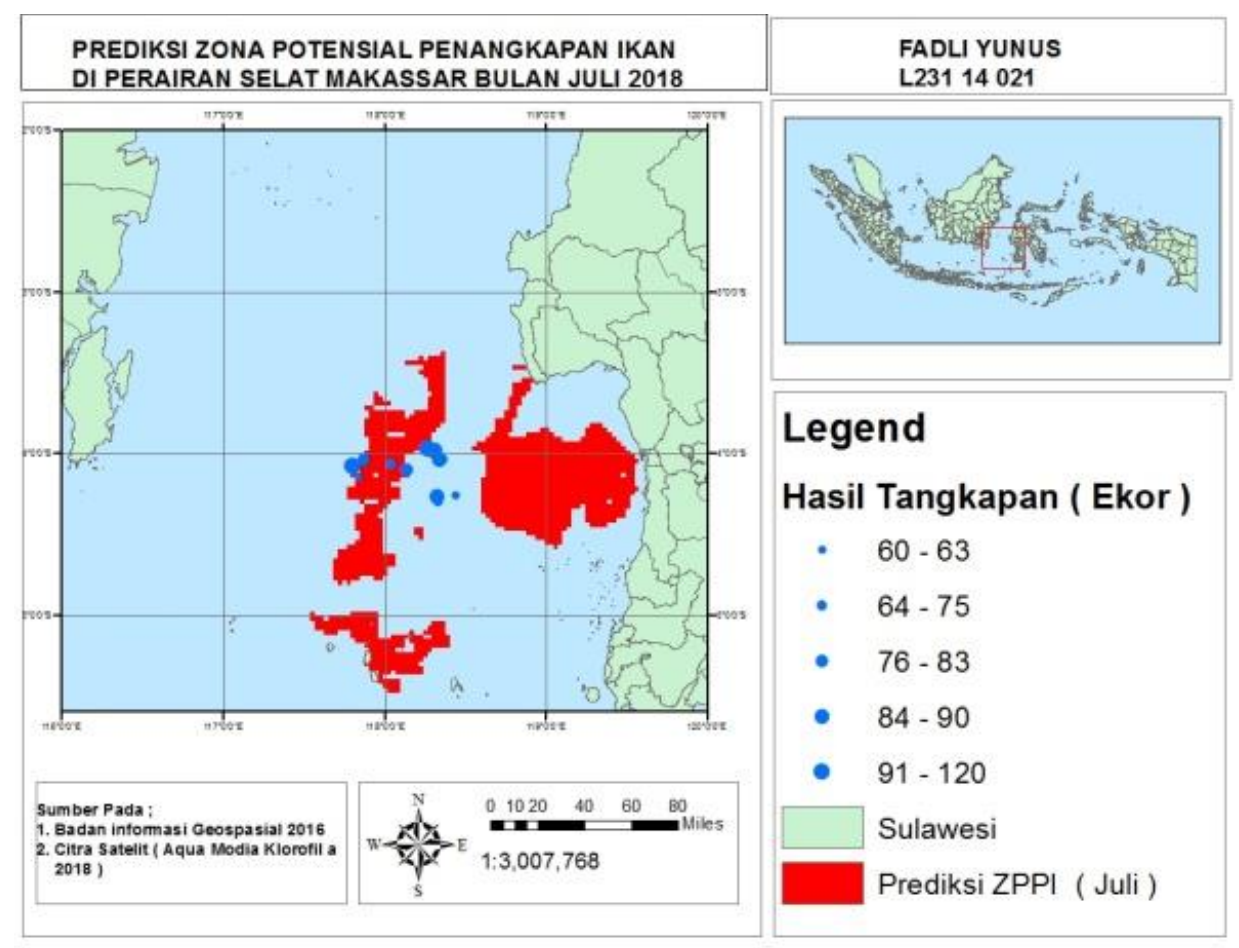

Gambar 17. Peta prediksi ZPPI ikan tongkol pada bulan Juli

Pada Gambar 18 luasan area yang terbentuk pada pertemuan suhu permukaan laut, klorofil - a, dan salinitas optimum adalah 28.091,321 $\mathrm{Km}^{2}$ pada bulan Agustus di Perairan Selat Makassar.

Pada bulan Agustus ZPPI ikan tongkol berada pada titik koordinat antara $3^{0} 25^{\prime}$
22.79 " LS sampai 5033 ' 19.33 " LS dan antara $117^{0} 21^{\prime} 39.6$ " BT sampai $119{ }^{\circ} 30$ ' 43.5 " BT atau berada sebelah barat Kabupaten Majene sampai Kabupaten Takalar. 


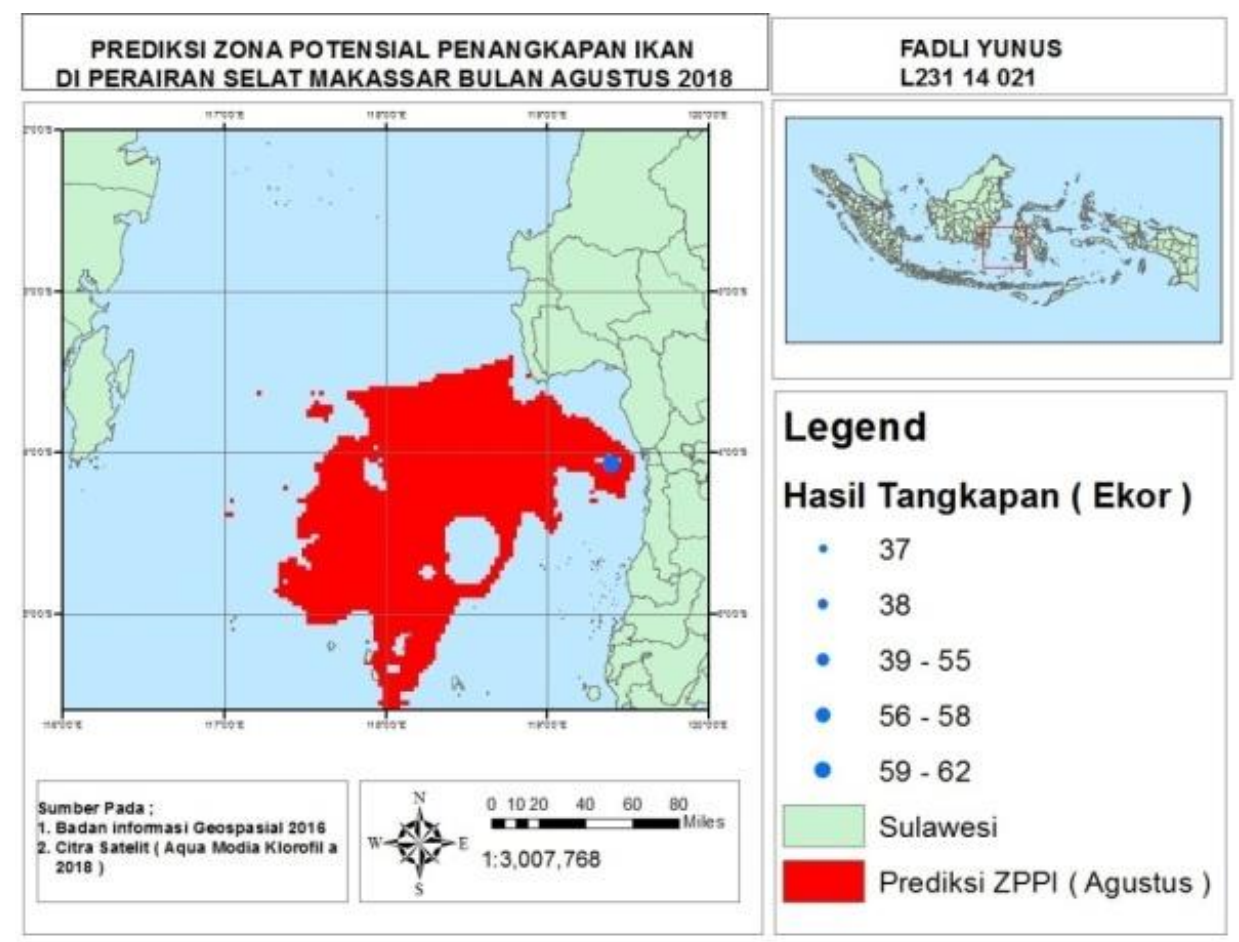

Gambar 18. Peta prediksi ZPPI ikan tongkol pada bulan Agustus

Zona potensial penangkapan ikan tongkol pada bulan September terdapat pada Gambar 19 dengan total luas area 32.376,785 $\mathrm{Km}^{2}$ pada bulan September di Perairan Selat Makassar.
Bulan September ZPPI ikan tongkol berada pada titik koordinat antara $3^{0} 24^{\prime}$ 14.14 " LS sampai $5{ }^{0} 19$ ' 56.19 " LS dan antara $117^{\circ} 0^{\prime} 43.21^{\prime \prime}$ BT sampai $119^{\circ} 34^{\prime}$ 31.96 " BT atau berada pada sebelah barat Kabupaten Majene sampai Kota Makassar.

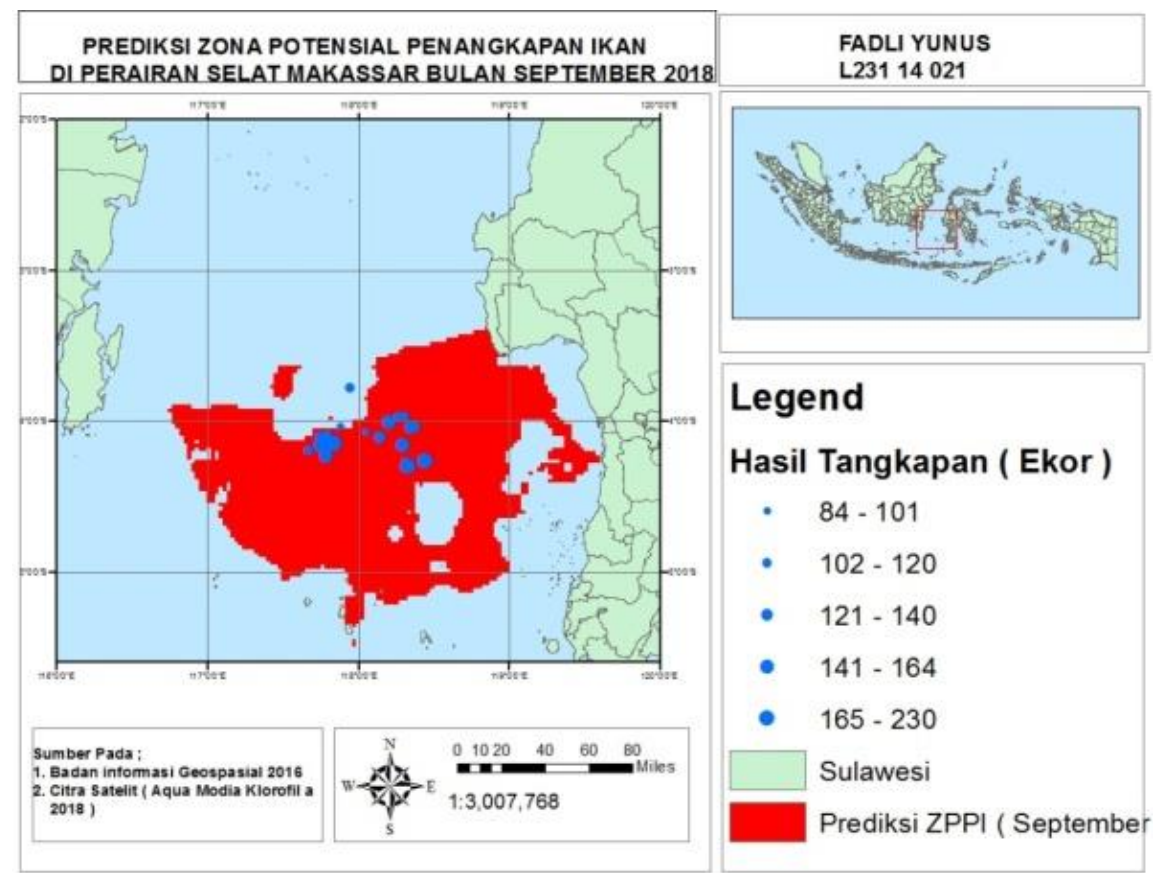

Gambar 19. Peta prediksi ZPPI ikan tongkol pada bulan September 
Gambar 20 menunjukkan area yang menjadi ZPPI ikan tongkol pada bulan Oktober di perairan Selat Makassar. Luas area ini $17.231,354 \mathrm{Km}^{2}$ yang dibentuk oleh suhu permukaan laut, klorofil - a, dan salinitas optimum ikan tongkol ( Euthynnus $s p$ ).
Pada bulan Oktober ZPPI ikan tongkol berada pada titik koordinat antara3 ${ }^{0} 40^{\prime}$ 15.39 " LS sampai $5^{0} 32$ ' 56.38 " LS dan antara $117{ }^{\circ} 9^{\prime} 5.77$ " BT sampai $119^{\circ} 0^{\prime}$ 38.89 " BT atau berada pada sebelah barat Kabupaten Pinrang sampai Kabupaten Takalar.

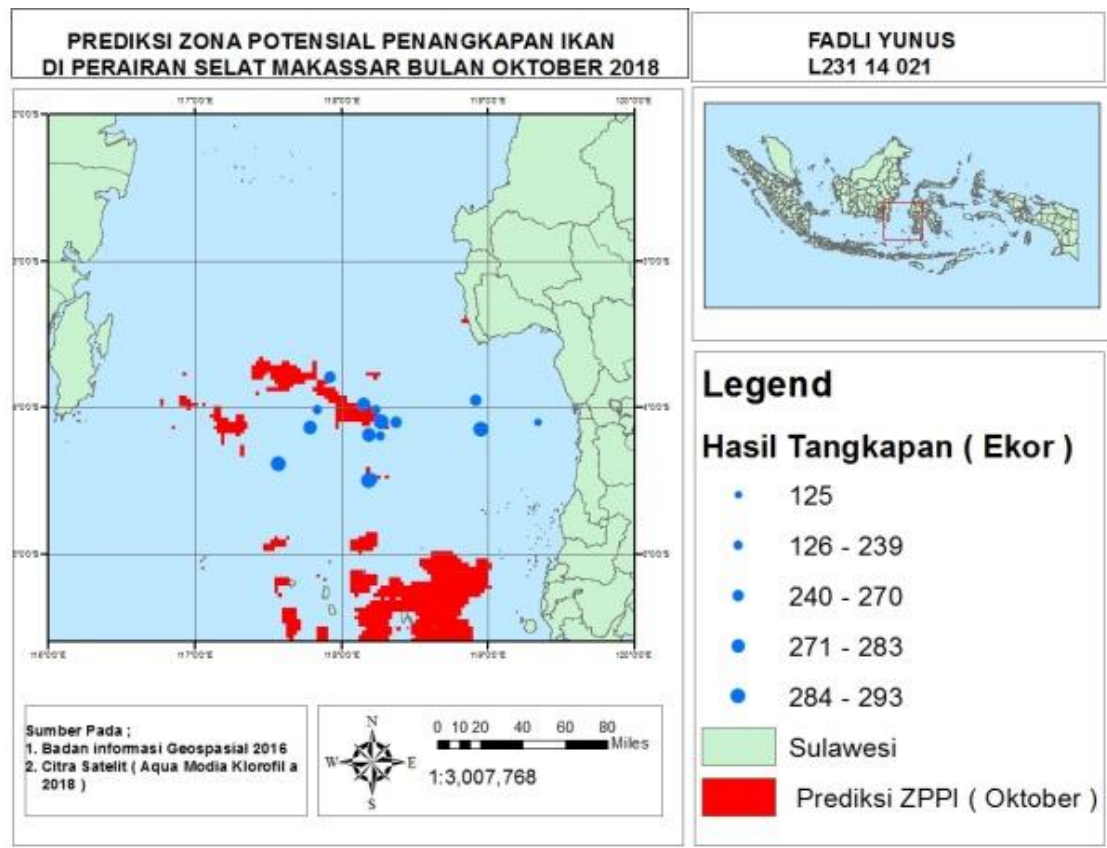

Gambar 20. Peta prediksi ZPPI ikan tongkol pada bulan Oktober

\section{KESIMPULAN}

Berdasarkan tujuan penelitian yang dilakukan maka dapat ditarik beberapa kesimpulan yaitu : Zona potensial penangkapan ikan tongkol berada pada titik $3^{0} 23^{\prime} 28.37$ " LS sampai $5^{\circ} 33$ ' 19.33 " LS dan antara $117^{\circ} 0$ '43.21" BT sampai $119{ }^{\circ} 34$ ' 31.96 " BT atau berada pada sebelah barat Perairan Kabupaten Majene sampai Kabupaten Takalar.

\section{DAFTAR PUSTAKA}

Adnan. 2010. Analisis Suhu Permukaan Laut dan Klorofil-a Data Inderaja Hubungannya dengan Hasil Tangkapan Ikan Tongkol (Euthynnus affinis) diPerairan Kalimantan Timur. Jurnal Amanisal PSP FPIK Unipatti Ambon: 1 - 12 .

Emiyati, K. T. setiawan, A. K. S. Manopo, S. Budhiman, Anneke KS. Manopo dan B. Hasyim.2015. Analisis Multiteemporal Sebaran Suhu Permukaan Laut di Perairan Lombok MEnggunakan Data Penginderaan Jauh Modis.Deteksi Parameter 


\section{Jurnal IPTEKS PSP. Vol. 6 (11) April 2019: 1-20}

Geofisik dan Diseminasi penginderaan jauh. Pusat Pemanfaatan penginderaan Jauh, Lapan: $470-479$.

Gomez, F. A. Montecinos, S. Hormazabal, L. A. Cubilos, M. C. Ramirez, and F.P. Chavez. 2012. Impact or spring upwelling variability off southern - central Chile onmcommon sardine (Strangomera benticki) recruitment. Fish.Ocenogr. 21(6): $405-414$.

Jufri, A. M. A Amran dan M Zainuddin.2014. Karakteristik Daerah Penangkapan Ikan Cakalang Pada Musim Barat Di Perairan Teluk Bone. Jurnal IPTEKS PSP, Vol. 1 (1): 1 - 10

Nontji, A. 1993. Laut Nusantara. Djambatan. Jakarta.

Odum, E. P. 1971. Fundamentals of Ecology: Thirthy Edition. Philadelphia: $546 \mathrm{Hal}$.

Polovina, J. J., E. Howel., D. Kobayahi, and M. P. Seki. 2001. The Transtition Chlorophyll Font, a Dynamic Global Featur defining Migration and Habitat for Marine Resources. Progress in Oceanogr 49. 469 - 483.

Safruddin dan M. Zainuddin. 2007. Mapping Scads Fishing Ground Based on the Relationship between Catch Data and Oseanografic Factors in Bone Coastal Waters. Torani Jurnal, ISSN 0853-4489. Vol. 17 (5) (special edition): $192-200$.

Sandi, Y. 2014. Clusterisasi Migrasi Ikan Tuna, Tongkol, Dan Cakalang Di Teluk bone dan Peran Daerah Dalam Pengelolaan Berkelanjutan. Dalam Prosiding Simposium Nasional Pengelolaan Perikanan
Tuna Berkelanjutan, Bali, $10-1$ Desember 2014.Dinas Kelautan dan Perikanan Kab.Bulukumba hal. VI 215 $-228$.

Tangke, J.CH. Karuwal, M. Zainuddin, dan A. Mallawa. $2015 . \quad$ Sebaran SuhuPermukaan Laut Dan Klorofila Pengaruhnya Terhadap Hasil Tangkapan Yellowfin Tuna (Thunnus albacares) Di Perairan Laut Halmahera Bagian Selatan. Jurnal IPTEKS PSP, Vol.2 (3) April 2015: 248-260.

Zainuddin, M., A. Nelwan, M.I. Hajar, A. Farhum, M. Kurnia, Najamuddin, Sudirman. 2013. Pemetaan Zona Potensial Penangkapan Ikan Cakalng Periode April - Juni di Teluk Bone dengan Teknologi Remote Sensing. Jurnal Penelitian Perikanan Indonesia, Vol. 19 (3): 167 $-173$.

Zulkhasyni dan Andriyeni, 2014. Musim Penangkapan Ikan Tongkol (Euthynnus sp) Di Perairan Kota Bengkulu, Laporan Hasil Penelitian. Fakultas Pertanian Universitas Prof. Dr. Hazairin, Sh Bengkulu. 